\title{
Glomerella leaf spot in apple: validation of proposed diagrammatic scale and efficiency of fungicides
}

\author{
Mancha de Glomerella em macieira: validação de escala diagramática proposta e \\ eficiência de fungicidas
}

\author{
Lígia Sayko KowataI Michele Strapasson $^{\mathrm{I}}$ Márcio Alberto Challiol ${ }^{\mathrm{I}}$ \\ Louise Larissa May-De Mio'*
}

\begin{abstract}
A diagrammatic scale to assess Glomerella leaf spot severity (Colletotrichum spp) was developed and validated during the tryout of a fungicide efficiency experiment in the field. Apple leaves were collected for determination of minimum and maximum severity limits; intermediate levels were obtained according to "Weber-Fechner's stimulus-response law". Scale validation was performed by four raters, which estimated the severity in 100 leaves; with and without the use of the scale. An experiment was carried out in a commercial orchard in randomized blocks with 10 plants. The treatments and dosages (g $100 \mathrm{~L}^{-1}$ of water) used were: cyprodinil (15); pyrimethanil (30, 37.5, 45); propineb (140) e mancozeb (160) + tebuconazole (12.50), and a control (no spray). The incidence and severity in leaves; number of fruits, weight and incidence in fruit (harvest) and defoliation (after harvest) were evaluated. The proposed scale showed the levels of $0.08 ; 0.28 ; 0.99 ; 3.45 ; 11.23$ and $30.93 \%$. The scale was adequate for severity assessment; $R^{2}$ changed from 0.68 to 0.96 with the use of the scale. Pyrimethanil treatments did not control the disease. The incidence on fruit was 30 and on leaves $63 \%$. The incidence was reduced in $35.6 \%$ (propineb) and 33.7\% (mancozeb + tebuconazole) related to the control, these treatments were efficient to control the disease. The defoliation was $44 \%$ in the control against 9.6 and $2.5 \%$ to propineb and mancozeb + tebuconazole.
\end{abstract}

Key words: Malus domestica, Colletotrichum spp, chemical control, disease quantification.

\section{RESUMO}

Neste estudo, foi desenvolvida uma escala diagramática para avaliação da mancha das folhas da macieira (Colletotrichum spp) e testada em experimento de controle químico. Folhas de macieira com diferentes níveis de severidade foram coletadas (Campo Largo-PR) para determinação dos limites mínimos e máximos. Os níveis intermediários foram obtidos pela "lei do estímulo visual de Weber-Fechner". A escala foi validada por quatro avaliadores, estimando a severidade em 100 folhas, com e sem uso da escala. Os tratamentos e as dosagens ( $100 \mathrm{~L}^{-1}$ de água) utilizados foram: ciprodinil (15); pirimetanil (30); (37,5); (45); propinebe (140) e mancozebe $(160)+$ tebuconazole $(12,5)$ em quatro blocos ao acaso contendo 10 plantas. Foram avaliadas a incidência e severidade em folhas, a desfolha em pós-colheita e o número de frutos, o peso e a incidência da doença em frutos (colheita). A escala proposta apresentou os níveis de 0,$08 ; 0,28 ; 0,99$; 3,$45 ; 11,23$ e $30,93 \%$, sendo adequada para avaliar severidade. O coeficiente de determinação foi de 0,68 e 0,96, com e sem o uso da escala. Pirimetanil não controlou a doença. A incidência em frutos foi de 30 e 63\% nas folhas. Foi observada redução da incidência de 63,7 para 35,6 (propinebe) e 33,7\% (mancozebe + tebuconazole), em comparação com o tratamento sem pulverização, sendo os dois referidos produtos eficientes no controle da doença. A desfolha foi de $44 \%$ na testemunha contra 9,6 e 2,5\% para propinebe e mancozebe + tebuconazole.

Palavras-chave: Malus domestica, Colletotrichum spp, controle químico, quantificação de doença.

\section{INTRODUCTION}

Glomerella Leaf Spot (GLS) is caused by the fungus Colletotrichum gloeosporioides (Penz.) Penz. \& Sacc., C. acantatum J.H. Simmonds and Glomerella cingulata (Stonem) Spauld \& Schrenk (CRUSIUS et al., 2002). Apple Leaf Spot and 'Gala' leaf spot are others name form the same disease.

IDepartamento de Fitotecnia e Fitossanitarismo, Universidade Federal do Paraná (UFPR). Rua dos Funcionários, 1540, Juveve, 80035-050, Curitiba, PR, Brasil. E-mail: maydemio@ufpr.br. *Autor para correspondência. 
In the state of Paraná, the GLS occurrence was described in 1983, and since then, the disease has been occurring yearly in all apples producing region of Brazil (LEITE et al., 1988). Despite the Glomerella leaf spot importance, there were few standard methods for disease assessment. The researches require reliable, accurate and precise quantification methods, standing out the significance of diagrammatic scale elaboration to reduce the subjectivity of the estimate (GIGLIOTI \& CANTERI, 1998). The development of a scale could be useful to evaluate disease epidemic progress in field, beyond the efficiency of fungicides in disease control.

Usually, the GLS fungicide control in the state of Paraná has been accomplished using only two active ingredients (tebuconazole and mancozeb), applied more than 6 times per season. Concerning to the recommendations of the Integrated Production Apple (IPA) - Brazil, the number of applications with these fungicides is restricted per season following some rules: the dithiocarbamate interventions must be alternated with fungicides of other chemical groups, with dosages limited to $4 \mathrm{~kg} \mathrm{ha}^{-1}$; for tebuconazole, the sum of treatments using Sterol Biosynthesis Inhibitors (SBIs) must not exceed six applications per season (VALDEBENITO-SANHUEZA et al., 2002).

Specific studies about efficiency of different fungicides for GLS control is necessary to provided tools to the management of this disease, avoiding or delaying resistance. The aim of this research was: (i) to develop and validate the diagrammatic scale for assessment of Glomerella leaf spot; and (ii) evaluate the applicability of this scale to test the efficiency of the fungicides cyprodinil; pyrimethanil; propineb compared with the standard treatment + mancozeb and tebuconazole to the control (no spray) in the control of GLS in Campo Largo County, PR.

\section{MATERIAL AND METHODS}

Elaboration and validation of diagrammatic scale to assess Glomerella leaf spot severity.

Apple leaves showing different severity levels were collected in commercial orchard, cv Gala, spacing 2x0.5m, planted in 2001, in Campo Largo County (PR). From the total of 250 collected, 100 dried leaves were selected $\mathrm{s}$ and the area of symptoms (leaf lesion areas) was quantified using Win Rhizo equipment, LA1600 mark (Regent Instruments Inc., Canada).

It was determined the apple leaves with the least and greatest severity, therefore establishing the lower and upper limits of the diagrammatic scale. The four intermediate levels of severity were mathematically determined according to Weber-Fechner's stimulusresponse law (HORSFALL \& BARRATT, 1945). The validation was performed based on estimation of 100 apple leaves showing rust symptoms at different severity levels, assessed by four persons, without previous contact with the scale and using the scale. The accuracy and precision of the assessments was verified by the coefficient of determination $\left(R^{2}\right)$ of the regression line. The accuracy of the estimates was determined by t-test applied to the slope coefficient (b) to check whether they were significantly different from '1.0', intercept (a) significantly different from 0 and $\mathrm{R}^{2}$ from ' 1 ' and variance of the absolute errors (estimated severity minus actual severity) for each assessment (NUTTER JR. \& SCHULTS, 1995).

Using a fungicide control experiment to assess the applicability of the scale

The experiment was installed in the same orchard described above, with seven treatments, four replicates, 10 plants in each replicate using randomized blocks, the six central plants were evaluated. The pulverization started in vegetative growth (November $1^{\text {st }}$ 2003), was repeated each 10 days until February $9^{\text {th }}$ 2004. The volume spray solution applied was $1.5 \mathrm{~L}$ per plant. The treatments and the actives ingredients (g $100 \mathrm{~L}^{-1}$ of water) used were: cyprodinil (15); pyrimethanil (30); (37.5); (45); propineb (140) e mancozeb (160) + tebuconazole (12.5) and control (no spray). Others cultural practices as fertilization and herbicide application were realized by the producer criterion.

The evaluation was carried out in three distinct periods: pre-harvest; harvest and post-harvest, assessing the symptoms in fruits and leaves. In the pre-harvest, GLS symptoms were evaluated in 40 leaves/parcel and eight fruits/parcel (December $16^{\text {th }}$ 2003). The number and weight of fruits and the incidence of GLS were determinate during the harvest. In the postharvest, the disease incidence was verified using 40 leaves/parcel on January $6^{\text {th }}$ and $20^{\text {th }}$; and February $2^{\text {nd }}$ 2004. The disease progress curve was assessed in three marked twigs at medium part of apple plants by incidence (number of leave with symptoms in total leaves of the twig) and severity (using the proposed scale). The defoliation (\%) was evaluated after the harvest (February $\left.2^{\text {nd }} 2004\right)$. Three twigs were marked per repetition. The infection of the pathogen occurred naturally. The area under the disease-progress curve for incidence before harvest (AUDPC) was calculated for each subplot according to SHANER \& FINNEY (1977) and these were analyzed by analysis of variance. The correlation analyze was used to discriminated efficiency of pyrimethanil dosage to be compared in 
chemical control. The statistical analyze was done by Statistica 8.0 program (STATSOFT, 2008). The data were verified as homogeneity of variances by Bartlett test. The variables which variances were homogeneous were tested by the F-test (ANOVA). The means were compared by Tukey test $(\mathrm{P}<0.05)$.

\section{RESULTS AND DISCUSSION}

Elaboration and validation of diagrammatic scale to assess Glomerella leaf spot severity

The proposed scale was composed by six severity levels $0.08 ; 0.28 ; 0.99 ; 3.45 ; 11.23 ; 30.93 \%$ (Figure 1). Graphics showing linear regression were elaborated and observed the coefficients of determination and the equation of the straight line (Table 1). Accuracy, represented by the degree of proximity of an estimate and real mean (NUTTER \& SCHULTZ, 1995), measured by the intercepts $(a)$ and by the slope coefficients $(b)$ of the regression line between actual and estimated values (Table 1). The intercept coefficient (a) was statistically different from ' 0 ', in both treatments. The statistical analyze ( $t$ test) pointed the slope $(b)$ values for the regression line statistically equal to $1(\mathrm{P}<0.05)$, using the scale (Table 1$)$. The ' $b$ ' without using the proposed scale did not differ significantly than 1 . The statistical analyses showed that $\mathrm{R}^{2}$ values without using the scale is null hypothesis $\left(\mathrm{R}^{2}=1\right)$. Estimated severities by raters, using the diagrammatic scale, were near from real values for all raters. It was observed an average increase in $\mathrm{R}^{2}$ of approximately $30 \%$ (Table 1 ). The raters showed good precision using the diagrammatic scale, the $\mathrm{R}^{2}$ ranged from 0.93 to 0.99 , while the result of the rates previous to the use of the scale, $\mathrm{R}^{2}$ ranged from 0.68 to 0.79 . The obtained results were better than the observed values in others studies. A diagrammatic scale to assess downy mildew (Peronospora manshurica) severity in soybean (Glycine max) leaves, $\mathrm{R}^{2}$ values varied from 0.71 to 0.92 (without using the scale) and 0.86 to 0.97 (using the scale) (KOWATA et al., 2008). $\mathrm{R}^{2}$ values obtained by using the diagrammatic scale were

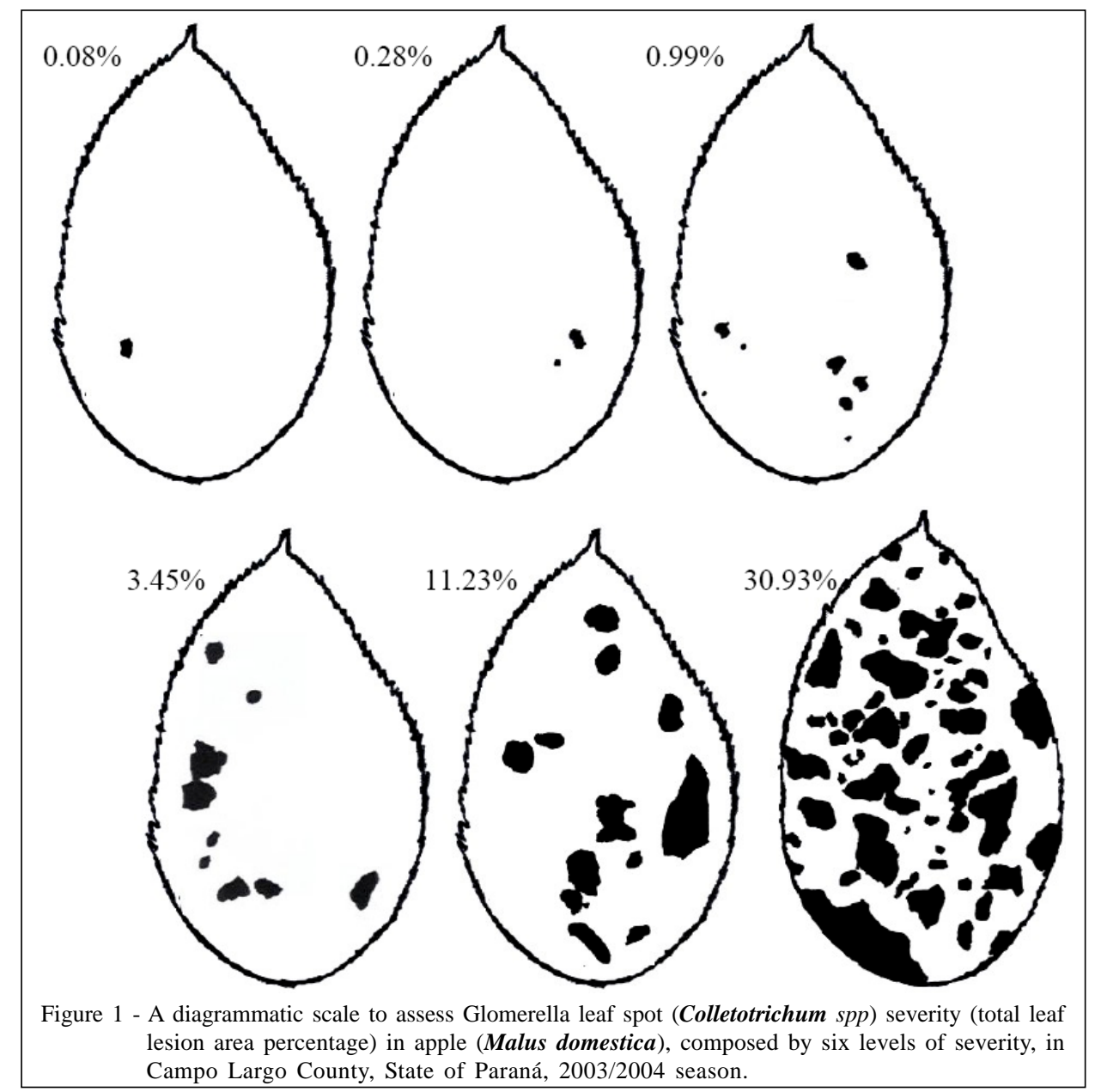

Ciência Rural, v.40, n.7, jul, 2010. 
Table 1 - Intercepts (a), slope coefficients $(b)$, and coefficients of determination $\left(\mathrm{R}^{2}\right)$ of the regression line for actual (independent variable) versus estimated severity (dependent variable) of 100 leaves of apple (Malus domestica) showing Glomerella leaf spot (Colletotrichum spp) symptoms, performed by four raters (with and without using the diagrammatic scale). Campo Largo County, State of Paraná. 2003/2004 season*.

\begin{tabular}{|c|c|c|c|c|c|c|}
\hline \multirow{2}{*}{ Raters } & \multicolumn{3}{|c|}{------------'without using the diagrammatic scale------------- } & \multicolumn{3}{|c|}{-------------with using the diagrammatic scale------------- } \\
\hline & a & $\mathrm{b}$ & $\mathrm{R}^{2}$ & A & $\mathrm{b}$ & $\mathrm{R}^{2}$ \\
\hline 1 & 0.73 & 0.89 & 0.69 & 0.47 & 1.01 & 0.98 \\
\hline 2 & 2.74 & 0.72 & 0.79 & 1.53 & 1.09 & 0.93 \\
\hline 3 & -0.70 & 1.46 & 0.80 & 0.01 & 1.06 & 0.99 \\
\hline 4 & 1.99 & 0.94 & 0.46 & -0.57 & 0.94 & 0.97 \\
\hline mean & 1.19 ns $( \pm 0.75)$ & $1.00 \mathrm{~ns}( \pm 0.14)$ & $0.68 \mathrm{~ns} B( \pm 0.07)$ & 0.36 ns $( \pm 0.44)$ & $\left.1.02^{*} \pm 0.03\right)$ & $0.97^{*} \mathrm{~A}( \pm 0.01)$ \\
\hline
\end{tabular}

${ }^{n s}$ No significative - situations in which the null hypothesis $(a=0$ or $b=1)$ was rejected by t-test $(\mathrm{P}<0.05)$. ${ }^{*}$ Significative, $\mathrm{b}=1$ and $\mathrm{R}^{2}=1$ by $t$ test $(\mathrm{P}>0.05)$. Means followed by different letters differ significantly $(\mathrm{P}<0.05)$ according to Tukey test, capital letters are referents analyze between treatments: with and without using the diagrammatic scale. ( \pm standard error).

statistically different and higher when compared with $\mathrm{R}^{2}$ values without using the scale $(\mathrm{P}<0.05)$, indicating precision of data.

The precision of data were also verified in variance of the absolute errors. The variance was higher without using the scale; the values of estimate severity were dispersed (data not showed). When the scale was used, the differences between absolute errors of raters were concentrated in the $10 \%$ range. This result was satisfactory and was equal to the required level in training of severity evaluation in software as Distrain (TOMERLIN \& HOWELL, 1988). Tools used to measurement of estimate severity, as diagrammatic scale, provide more reliability in monitoring. All this reaffirm the necessity of patterned methods for adequate assessment of disease quantification.

Among studied raters, the best results belongs to rater 3 , using the proposed scale, neither variance of the absolute errors value above than $10 \%$ was verified and $\mathrm{R}^{2}$ was really close to $1(0.99)$ (Table 1 ), good accuracy and precision data can be attributed to training and experience of raters in disease quantification. Rater 4 showed tendency to sub estimate the severity. GODOY et al. (2006) observed that $R^{2}$ values for inexperienced raters ranged from 0.67 to 0.90 using the scale, whereas for experienced raters they ranged from 0.89 to 0.95 . For experienced raters, who had had previous contact with the other scales, improvements were not as significant as for inexperienced raters. According to the presented results, the proposed scale to apple GLS, improved the accuracy and precision of raters providing estimate severity near the actual values.

The scale validation occurred after using it in an experimental test about chemical control. So, during the research was observed one sub-estimation of $5 \%$ (in mean) when comparing to real values. The $t$ test showed differences between real and estimate severity $(\mathrm{P}<0.05)$, estimate severity was sub-estimated (9.3\%) when comparing to real severity (14.4\%) (Table 2). Despite of this difference, real proportion was kept in severity evaluation. The problem was resolved with specific training to raters, comparing real with scale values. Additionally, correlation test (r) was realized between real and estimate severities in chemical control evaluation. The minor value was in the control (0.6) and the highest on mancozeb + tebuconazole (0.8) (Table 2). Proposed scale is adequate to disease assessment, being indicated to epidemiologic studies of GLS in field and fungicides efficiency evaluation or others control methods.

Using a fungicide control experiment to assess the applicability of the scale and efficiency of the fungicides to control Glomerella leaf spot

The productivity variables did not show correlation in different dosages of pyrimethanil and the disease incidence in leaves increased with pyrimethanil dosage (Figure 2). Concerning to these results, treatments with this product were not considered on the comparative analyze of chemical control. The real severity was less in mancozeb + tebuconazole $(8.8 \%)$ treatment than in cyprodinil (16.4\%) and control (no spray) (18.6\%), to Tukey test $(\mathrm{P}<0.05)$ (Table 2). Estimate severity was higher when no fungicide was applied and different when compared to propineb and mancozeb + tebuconazole treatments, respectively 7.4 and $6.1 \%$. The control of the disease can avoid premature defoliation, for example, in the region studied the leaves fell down after $30 \%$ of severity in apple cv. Gala. When the delay of the leaf fall occurs, apple plants will store more energy in quantity and 
Table 2 - Variables assessed for scale validation and chemical control of Glomerella leaf spot (Colletotrichum spp) in apple (Malus domestica). Campo Largo County, State of Paraná. 2003/2004 season*.

\begin{tabular}{|c|c|c|c|c|c|c|c|c|c|c|}
\hline \multirow{3}{*}{$\begin{array}{l}\text { Variables } \\
\text { Sev. real (\%) }\end{array}$} & \multicolumn{8}{|c|}{----------------------------------Treatment (i.a g.100 L'1) ---------------------------------- } & \multirow{2}{*}{\multicolumn{2}{|c|}{ Mean }} \\
\hline & \multicolumn{2}{|c|}{ Control (0) } & \multicolumn{2}{|c|}{ Cyprodinil (15) } & \multicolumn{2}{|c|}{ Propineb (140) } & \multicolumn{2}{|c|}{ MTeb. $(200+12.5)$} & & \\
\hline & $18.6 \mathrm{a}$ & \pm 1.4 & 16.4 a & \pm 1.1 & $13.1 \mathrm{ab}$ & \pm 1.3 & $8.9 \mathrm{~b}$ & \pm 1.3 & $14.4 \mathrm{a}$ & \pm 0.9 \\
\hline Sev. estimate (\%) & $12.9 \mathrm{a}$ & \pm 1.1 & $10.2 \mathrm{ab}$ & \pm 0.7 & $7.4 \mathrm{~b}$ & \pm 0.1 & $6.1 \mathrm{~b}$ & \pm 1.1 & $9.3 \mathrm{~b}$ & \pm 0.6 \\
\hline r ( real x estimate) & 0.6 & -- & 0.6 & -- & 0.6 & -- & 0.8 & -- & -- & -- \\
\hline \multicolumn{11}{|l|}{ Pre-harvest ${ }^{\mathrm{x}}$} \\
\hline Incidence in fruits (\%) ${ }^{\mathrm{y}}$ & $15.6 \mathrm{~ns}$ & \pm 13.5 & 15.6 & \pm 7.8 & 7.8 & \pm 6.8 & 0.0 & \pm 0.0 & -- & -- \\
\hline Incidence in leaves (\%) & 63.7 a & \pm 4.0 & $48.7 \mathrm{ab}$ & \pm 6.1 & $35.6 \mathrm{~b}$ & \pm 5.2 & $33.7 \mathrm{~b}$ & \pm 5.4 & -- & -- \\
\hline \multicolumn{11}{|l|}{ Harvest } \\
\hline Number of fruits & $235.5 \mathrm{~ns}$ & \pm 41.3 & 301.7 & \pm 33.1 & 248.2 & \pm 42.5 & -- & -- & -- & -- \\
\hline Weight of fruits (g) & $72.6 \mathrm{~ns}$ & \pm 9.4 & 72.2 & \pm 7.0 & 89,8 & \pm 13.5 & -- & -- & -- & -- \\
\hline Incidence in fruits ${ }^{\mathrm{w}}$ & 30.7 a & \pm 8.3 & $20.0 \mathrm{ab}$ & \pm 5.3 & 8.7 bc & \pm 1.5 & $2.0 \mathrm{c}$ & \pm 0.5 & -- & -- \\
\hline AUDPC $^{k}$ & 2692.6 a & \pm 4.8 & 2396.9 a & \pm 5.4 & $2234.1 \mathrm{ab}$ & \pm 9.7 & $1556.9 \mathrm{~b}$ & \pm 15.7 & -- & -- \\
\hline Defoliate (\%) & $44.5 \mathrm{a}$ & \pm 2.8 & $23.9 \mathrm{ab}$ & \pm 11.9 & $9.6 \mathrm{~b}$ & \pm 5.3 & $2.5 \mathrm{~b}$ & \pm 1.9 & -- & -- \\
\hline
\end{tabular}

Abbreviations: Sev.: severity. Mteb.: mancozebe and tebuconazole. ${ }^{\text {ns }}$ No significative. ${ }^{*}$ Values with different letters differ significantly according to Tukey test $(\mathrm{P}<0.05)$. -- No evaluated. ${ }^{\mathrm{X}}$ data collected in December, 16 of 2003. ${ }^{\mathrm{y}}$ Mean of eight fruits. ${ }^{\mathrm{w}}$ Data transformed by vx +1 . ${ }^{k}$ Area under the disease progress curve for Glomerella incidence in leaves From January to February. ( \pm standard error).

time. Consequently, the productivity and fruits will be higher in the next season, prolonging the time of production in the orchard.

AUDPC of GLS incidence was higher in control (2692.6), which did not differ statistically from cyprodinil (2396.9) and propineb (2234.1) (Table 2). Mancozeb + tebuconazole showed lower AUDPC (1556.9) and equal to propineb. Mancozeb + tebuconazole and propineb treatments promoted high reductions after harvest defoliation (Table 2). These treatments were statically less (2.5\% for mancozebe + tebuconazole and $9.6 \%$ for propineb) than cyprodinil (23.9\%) and the control (44.5\%). Bigger defoliation in experimental fields happened in February, early to natural defoliation (late autumn). The premature leaf fall is worrisome in orchards due to affecting the production and longevity of plants. Under favorable condition to the epidemic, as high temperatures and long moisture periods, in south of Brazil, 20 pulverizations per season are realized with mancozeb and dithianon to control the disease (VALDEBENITOSANHUEZA et al., 2002). According to the same authors, mancozeb, captan, phosmet, fluazinam, propineb, dithianon, chlorothalonil and benzimidazoles can be applied in commercial orchards on 10 days intervals, after each $30 \mathrm{~mm}$ rainfall.

The evaluation carried out before the harvest showed that the treatments did not differ in disease incidence in fruits. The GLS incidence in leaves was lower in mancozeb + tebuconazole (33.7\%) not differing statistically to the propineb treatment (35.6\%)
(Table 2). The results indicate propineb and mancozeb + tebuconazole can be recommended to GLS control due to the efficiency in reduction of the disease incidence in leaves. At harvest, the 'number of fruits' did not present differences among treatments (Table 2), the same was observed for variable 'weight of fruits' (g). The association mancozeb + tebuconazole showed once more lower levels of GLS incidence in fruits, which differed statistically from the others fungicides. These results and leaf disease incidence denote GLS control with mancozeb + tebuconazole. THOMAS et al. (2008), assessing fungicides for anthracnose (Colletotrichum Iupini) control of lupin, verified that the application of azoxystrobin, chlorothalonil, mancozeb and copper oxychloride fungicides, 1 day prior to infection, were highly effective, while tebuconazole, benomyl and carbendazim were less effective. CRUSIUS et al. (2002) in a study about epidemiology of GLS observed that two sprays of copper oxychloride (at $0.3 \%$ ) reduced the fungus initial inoculum by $65-84.6 \%$ in buds and 85.6-93.7\% in twigs, but had no effect on the early season progress of the disease.

BONETI et al. (2002) described occurrence of anticipated leaf fall in more than $75 \%$ under favorable conditions of humidity and temperature, easily found in cultivate areas. Climate conditions favorable to pathogen development are temperatures equal or higher than $18^{\circ} \mathrm{C}$ GLS attack is intensified at temperatures above $24^{\circ} \mathrm{C}$. CRUSIUS et al. (2002) related that the pathogen overwintered in dormant buds and twigs but not in fallen leaves or fruit mummies. The severity 


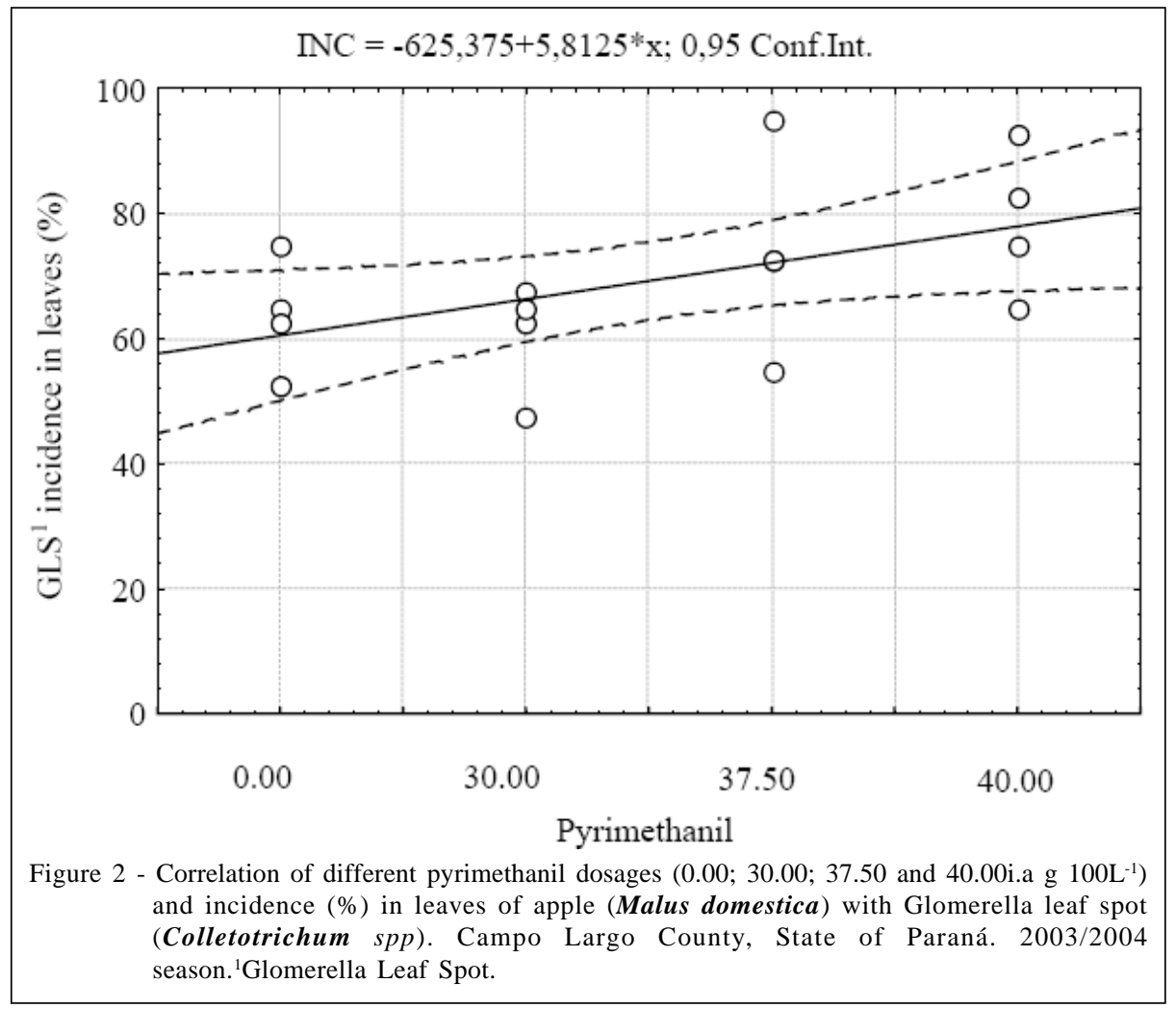

increased proportionally to elevation of temperature from 14 to $26-28^{\circ} \mathrm{C}$. The duration of leaf wetness required for infection ranged from two hours at $30^{\circ} \mathrm{C}$ to $32 \mathrm{~h}$ at $16^{\circ} \mathrm{C}$. There are no reports of experiments with fungicides in Glomerella leaf spot on the literature. Some of these products were tested to control apple scab: cyprodinil pyrimethanil, propineb and trifloxyztrobin (BERTON et al., 2007); the effect of the fungicides was not evidenced for systemic compounds and neither phytotoxicity over spurs and leaves nor russeting on fruits were observed after ten fungicide sprays. The results presented in this paper can help the producers and researches assess and control the disease, but continuous development of strategies of control and epidemiological studies are still a great concerning to the integrated management of this disease.

\section{CONCLUSION}

The proposed scale to assessment Glomerella leaf spot (GLS) was adequate to disease quantification. The tebuconazole and mancozeb in association reduced GLS severity and incidence. Cyprodinil and pyrimethanil treatment was not efficient to reduce severity and incidence of GLS.

\section{REFERENCES}

BERTON, O. et al. Cyprodinil, pyrimethanil, propinebe e trifloxystrobin no controle da sarna da macieira. Scientia Agraria, v.8, n.2, p.173-178, 2007. Available from: <dialnet.unirioja.es/ servlet/fichero_articulo?codigo $=2908088 \&$ orden $=0>$. Accessed: May 15, 2008.

BONETI, J.I. da S. et al. Doenças fúngicas foliares. In: EPAGRI. A cultura da macieira. Florianópolis: Epagri, 2002. 743p.

CRUSIUS, L.U. et al. Epidemiology of apple leaf spot. Fitopatologia brasileira, v.27, p.65-70, 2002. Available from: $<$ http://www.scielo.br/scielo.php?script=sci_arttext\&pid=S010041582002000100010>. Accessed: May 15, 2008. doi: 10.1590/ S0100-41582002000100010.

GIGLIOTI, E.A.; CANTERI, M.G. Desenvolvimento de software e escala diagramática para seleção e treinamento de avaliadores do complexo broca-podridões em cana-de-açúcar. Fitopatologia Brasileira, v.23, p.359-363, 1998.

HORSFALL, J.G.; BARRAT, R.W. An improved grading system for measuring plant diseases. Phytopathology, v.35, p.655, 1945. Available from: <http://www.garfield.library.upenn.edu/ classics1986/A1986A666500001.pdf>. Accessed: May 15, 2008.

GODOY, C.V. et al. Diagrammatic scale for assessment of soybean rust severity. Fitopatologia Brasileira, v.31, n.1, p.63-68, 2006. Available from: <http://www.scielo.br/ scielo.php? script = sci art text\&pid = S 0100 41582006000100011>. Accessed: May 15, 2008. doi: 10.1590/ S0100-41582006000100011.

Ciência Rural, v.40, n.7, jul, 2010. 
KOWATA, L.S. et al. Escala diagramática para avaliar severidade de míldio na soja. Scientia Agraria (UFPR), v.9, p.105-110, 2008. Available from: <http://ojs.c3sl.ufpr.br/ojs2/index.php/ agraria/article/view/10145/8184>. Accessed: Jun 08, 2009.

LEITE Jr., R.P. et al. Ocorrência de mancha foliar de Glomerella em macieira no Estado do Paraná. Londrina: IAPAR, 1988. 6p. (IAPAR, Informe de Pesquisa, 81).

NUTTER JR., F.W.; SCHULTZ, P.M. Improving the accuracy and precision of disease assessments: selection of methods and use of computer-aided training programs. Canadian Journal of Plant Pathology, v.17, p.174-184, 1995. Available from: <http://www.cps-scp.ca/download/cjpp-archive/Vol17/ CJPP17(2)174-184(1995).pdf>. Accessed: May 15, 2008.

SHANER, G.; FINNEY, R.E. The effect of nitrogen fertilization on the expression of slow-mildewing resistance in Knox wheat. Phytopathology, n.67, p.1051-1056, 1977. Available from: < h t t p://ww w. a p snet.org/phyto/P D F S / 1977 / Phyto67n08_1051.pdf>. Accessed: May 15, 2008. doi: 10.1094/Phyto-67-1051.
STATSOFT, Inc. STATISTICA for Windows (data analysis software system), version 8.0. Computer program manual, Quick Reference. Tulsa: Statsoft, Inc., 2008. 298p.

THOMAS, G.J. et al. Application of fungicides to reduce yield loss in anthracnose-infected lupins. Crop Protection, v.27, n.7, p.10711077, 2008. Available from: <http://www.sciencedirect.com/ science?_ob=ArticleURL\&_udi=B6T5T-4RWBCRX$1 \&$ \&user $=10 \&$ \&_coverDate $=07 \% 2 \mathrm{~F} 31 \% 2 \mathrm{~F} 2008 \&$ \&doc $=1 \&$ _fmt=high\&_orig=search\&_sort $=$ d\&_docanchor $=\& v i e w=c \& \_s e$ archStrId $=1333232322 \&$ rerunOrigin $=$ google\&_acct $=\mathrm{C} 0000$ $50221 \&$ \& version $=1 \&$ \&_url Version $=0 \&$ \&_userid $=$ 10\&md5=b76d142abb15ac609b71f67c6ceff728>. Accessed: May 15, 2008. doi:10.1016/j.cropro.2007.12.012.

TOMERLIN, Jr.; HOWELL, T.A. Distrain: a computer program for training people to estimate disease severity on cereal leaves. Plant Disease, v.72, p.455-459, 1988.

VALDEBEnito-SANHUEZA, R.M. et al. Manejo das doenças de verão na produção integrada de maçã. Bento Gonçalves: EMBRAPA, 2002. 12p. (Circular técnica EMBRAPA n.36). 